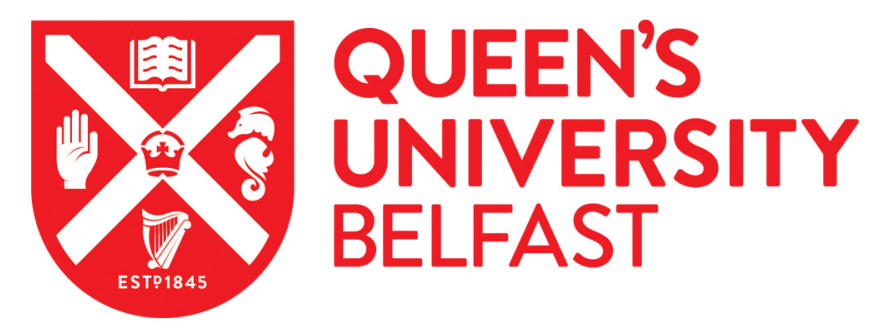

\title{
Ex-combatants and post-liberal peacebuilding in Northern Ireland: challenging cultures of militarism
}

Ganiel, G. (2019). Ex-combatants and post-liberal peacebuilding in Northern Ireland: challenging cultures of militarism. Peacebuilding. https://doi.org/10.1080/21647259.2019.1621003

\section{Published in:}

Peacebuilding

Document Version:

Peer reviewed version

Queen's University Belfast - Research Portal:

Link to publication record in Queen's University Belfast Research Portal

Publisher rights

(C) 2019 Informa UK Limited, trading as Taylor \& Francis Group. This work is made available online in accordance with the publisher's policies. Please refer to any applicable terms of use of the publisher.

\section{General rights}

Copyright for the publications made accessible via the Queen's University Belfast Research Portal is retained by the author(s) and / or other copyright owners and it is a condition of accessing these publications that users recognise and abide by the legal requirements associated with these rights.

Take down policy

The Research Portal is Queen's institutional repository that provides access to Queen's research output. Every effort has been made to ensure that content in the Research Portal does not infringe any person's rights, or applicable UK laws. If you discover content in the Research Portal that you believe breaches copyright or violates any law, please contact openaccess@qub.ac.uk. 


\section{Ex-Combatants and Post-Liberal Peacebuilding in Northern Ireland: Challenging Cultures of Militarism}

\section{Introduction}

In the wake of critiques of liberal peacebuilding, scholars are constructing alternative approaches to addressing violence. ${ }^{1}$ These 'post-liberal' approaches confirm the value of local peacebuilders responding to local needs as they transform relationships and institutions from below. This contrasts to liberal approaches, which are said to expect locals to fit in to institutions imposed from above. But as Richard Jackson has argued, even post-liberal approaches may not go far enough. ${ }^{2}$ This is because they perpetuate a fundamental assumption of liberal peacebuilding: that the military is a key actor in state-building and, as such, violence is a legitimate alternative to democratic politics. This leaves militarism unchallenged and prevents more liberating, pacifist forms of political engagement from emerging.

Northern Ireland is often considered a more or less successful case of negotiated political settlement and post-violence peacebuilding. The political institutions established after the 1998 Good Friday Agreement created a form of power-sharing which has allowed for a measure of democratic governance. But the structure of these institutions ensured that politics would continue to be dominated by ethno-religious political divisions, rather than

\footnotetext{
${ }^{1}$ Jacob Bercovitch and Richard Jackson, Conflict Resolution in the Twenty-first Century: Principles, Methods and Approaches (Ann Arbor: Michigan University Press, 2009); Roger Mac Ginty, International Peacebuilding and Local Resistance (Basingstoke: Palgrave, 2011); Oliver Richmond, 'Failed Statebuilding Versus Peace Formation', Cooperation and Conflict 48, no 3 (2013): 378-400; Oliver Richmond and Roger Mac Ginty, 'Where now for the Critique of the Liberal Peace?' Cooperation and Conflict 50, no. 2 (2015): 171-189.

${ }^{2}$ Richard Jackson, 'Post-Liberal Peacebuilding and the Pacifist State', Peacebuilding 6, no 1 (2018): 1-16.
} 
conventional left-right politics. Now, there is heightened uncertainty following the UK's June 2016 referendum vote to leave the European Union, which has raised concerns about what will happen with the border between Northern Ireland and the Republic of Ireland. Northern Ireland's Legislative Assembly has been suspended since January 2017, because the two largest parties, aligned with the ethno-religious blocs, have not agreed to form an Executive. And although Northern Ireland has been de-militarised in the sense that there is no longer a significant British Army presence and major paramilitary groups have decommissioned, some paramilitary groups remain and exert coercive control in localised areas. There are multiple everyday reminders of the conflict, including murals depicting soldiers and paramilitary fighters, memorials to the conflict, and media coverage around anniversaries of atrocities.

Despite these frequent reminders of militarism, few have questioned their impact on the present. This article explores how one small alliance of ex-combatants has begun to critique what they call Northern Ireland's 'cultures of militarism,' evaluating their efforts to 'start a conversation' about militarism with young people. The alliance's rather unique focus on militarism situates it within Jackson's 'post-liberal peace plus' approach to peacebuilding, providing an empirical case study of the opportunities and challenges of deconstructing militarism in a particular context.

The alliance is comprised of a handful of ex-combatants from British Army, and loyalist and republican ex-prisoner backgrounds. There is no official membership; rather, the men are loosely organised around the efforts of the facilitator, a former member of the Ulster Defence Regiment (UDR) and the regular British Army. ${ }^{3}$ They are friends and have worked

\footnotetext{
${ }^{3}$ The UDR was a regiment of the British Army established in 1970 to address the Troubles. It drew primarily on local recruits from the Protestant-Unionist-Loyalist (PUL) community. In 1992 it was amalgamated with the Royal Irish Rangers to form the Royal Irish Regiment in the form of Home Service Battalions.
} 
together on previous projects on an ad hoc basis. In 2015, the facilitator approached my university to discuss the alliance's concerns about militarism, radicalisation and approaches to history among young people. It could be said that these ex-combatants see their own communities $^{4}$ as what Lind and Luckham have called 'the insurgent margins' - places of 'persistent violent insecurity'. ${ }^{5}$ I agreed to work with the alliance on an action research project to explore the alliance's concerns and to help shape potential future engagement with young people.

The reintegration of ex-combatants into society has been recognised as a vital component of peacebuilding, in Northern Ireland and elsewhere. ${ }^{6}$ In Northern Ireland, the most extensive efforts to reintegrate ex-combatants have been community-based restorative justice (CBRJ) projects with ex-prisoners. There is evidence that these programmes have reduced paramilitary-style punishment attacks. ${ }^{7}$ Some researchers have argued that excombatants' experience of violence during the Troubles gives them the credibility and

\footnotetext{
${ }^{4}$ The term 'communities' is often used in Northern Ireland to refer to the two largest ethno-religious blocs. But these blocs are not monolithic. Disadvantaged socio-economic areas are more likely to overlap with the 'insurgent margins.'

${ }^{5}$ Jeremy Lind and Robin Luckham, 'Introduction: Security in the Vernacular and Peacebuilding at the Margins: Rethinking Violence Reduction', Peacebuilding 5, no. 2 (2017): 89-98, 89.

${ }^{6}$ Clare Dwyer, 'Expanding DDR: The Transformative Role of Former Prisoners in Community-Based Reintegration in Northern Ireland', International Journal of Transitional Justice 6, no. 2 (2012): 274-95; Hugo van der Merwe and Richard Smith, 'Ex-Combatants as Peacebuilders: Opportunities and Challenges', in Struggles in Peacetime, Working with Ex-Combatants in Mozambique: Their Work, Their Frustrations and Successes, ed. Bram Posthumus, Salomao Tirco Mungoi, Hugo van der Merwe, and Richard Smith (Amsterdam: Netherlands Institute for Southern Africa, 2006), 1-57.

${ }^{7}$ Harry Mika, Community Based Restorative Justice in Northern Ireland, Queen's University Belfast: Institute of Criminology and Criminal Justice, 2006), available at:

http://www.atlanticphilanthropies.org/app/uploads/2015/09/HMikaReport.pdf, accessed 30 April 2018.
} 
legitimacy to front these projects, and the leadership skills to implement them. ${ }^{8}$ Others have claimed ex-prisoners are well-positioned to provide 'moral leadership' in their communities, ${ }^{9}$ although critics have pointed out CBRJ projects could be giving paramilitaries a way to control their communities by other means. ${ }^{10}$ Working with young people is another area in which ex-combatants have contributed to peacebuilding. In Northern Ireland, the 'Prisons to Peace' programme in schools featured ex-prisoners warning the next generation about the consequences of taking up arms. ${ }^{11}$ The 'Prisons to Peace' team developed a 10-week curriculum in which pupils explored alternative perspectives on the conflict, culminating in a panel discussion with ex-prisoners. In a survey of pupils that completed the programme, the researchers found that they had increased their knowledge of the conflict, increased their support for non-violent methods for resolving conflict, and were more likely to be politically engaged. ${ }^{12}$ Simic and Milojevic's study of the 'Dialogues' programme in Serbia described a more ad hoc programme, where ex-combatants visited schools on a one-off basis. ${ }^{13}$ Simic and

\footnotetext{
${ }^{8}$ Kieran McEvoy and Harry Mika, 'Restorative Justice and the Critique of Informalism in Northern Ireland', British Journal of Criminology, 42 (2002): 534-562.

${ }^{9}$ Kieran McEvoy and Anna Eriksson, 'Restorative Justice in Transition: Ownership, Leadership, and 'Bottomup' Human Rights', in Handbook of Restorative Justice, ed. Dennis Sullivan and Larry Tifft (London: Routledge, 2006).

${ }^{10}$ Independent Monitoring Commission, 'February Report' (Belfast: Independent Monitoring Commission, 2007); Mika, Community Based Restorative Justice in Northern Ireland.

${ }^{11}$ Lesley Emerson, 'Conflict, Transition and Education for "Political Generosity": Learning from the Experience of Ex-Combatants in Northern Ireland', Journal of Peace Education 9, no. 3 (2012): 277-95.

${ }^{12}$ Lesley Emerson, Karen Orr and Paul Connolly, 'Evaluation of the Effectiveness of the "Prison to Peace: Learning from the Experience of Political Ex-Prisoners” Educational Programme’ (Belfast: Queen's University Centre for Effective Education, 2014).

${ }^{13}$ Olivera Simic and Ivana Milojevic, 'Dialogues between Ex-Combatants and Youth in Serbia: A Constructive use of War Experience', Peacebuilding 2, no. 3 (2014): 1-14.
} 
Milojevic identified the 'peacebuilding role' of 'Dialogues' as: 'bringing out "the elephant in the room" in speaking about the phenomenon of war, a discourse usually suppressed by Serbian society; socially and politically engaging young people; deconstructing the image of war as a heroic experience and, instead, exposing the reality of war; discussing the choices people make; and assisting ex-combatants in their long-term healing journey. ${ }^{14}$ Although 'Prisons to Peace' and 'Dialogues' have received favourable evaluations by academic researchers, the work of ex-combatants with young people is considered high-risk and it is difficult to find financial support for it. It took 'Prisons to Peace' many years of voluntary work in schools before it gained significant funding. 'Dialogues' was not funded and at the time of its evaluation, it was not clear if it would continue.

The alliance's focus on cultures of militarism is, as far as I know, unique in Northern Ireland and perhaps internationally. Other programmes in Northern Ireland also generally have not included state ex-combatants alongside ex-prisoners. This marks the alliance out as an interesting case of Jackson's 'post-liberal peace plus,' in as far as it encourages young people to reflect on both state militarism and paramilitarism. This article proceeds as follows. First, I outline the research methods. Then I describe cultures of militarism in Northern Ireland, relating the alliance's use of the term to research on militarism, militarisation and military masculinities. Next, I present results which confirm the alliance's hypotheses that some young people from their communities are vulnerable to cultures of militarism. I conclude by discussing the alliance's work as an example of Jackson's 'post-liberal peace plus,' arguing that despite evidence of potentially transformative impacts on young people, the alliance's work faces considerable obstacles in developing a sustainable programme. Peacebuilding in Northern Ireland relies heavily on state-based sources of funding, which may not welcome critiques of state militarism. Indeed the critique that sets the alliance apart

\footnotetext{
${ }^{14}$ Simic and Milojevic, 'Dialogues between Ex-Combatants and Youth in Serbia', 10.
} 
- and provides such potentially transformative power - may make it more difficult for it to attract the resources to match the ambition of its vision.

\section{Methods}

This project was guided by the ideals of action research, which is at once practical and normative: practical in that it involves researching the practical actions of people trying to 'make a difference', and normative in that the research participants (and the researcher) want their work to transform societies, politics or cultures in some way. Ideally, the participants and the researcher co-design and implement the project, producing results that shape their future actions. I was attracted to the project because of my commitment to action research, which has been an aspect of my previous work with faith-based groups. ${ }^{15}$ This was the first project of my career in which religion was not a main focus. My position was in many ways that of an outsider: I had not conducted research with ex-combatants or in schools or youth groups before so I was an unfamiliar face; I am a woman, and there are far more men than women among ex-combatants; and I am American-born so not easily-identifiable with either of the 'two communities' in Northern Ireland, although it is possible that because I am from an evangelical Protestant background I may be viewed more sympathetically by unionists. ${ }^{16}$ I secured seed funding from my university to cover the costs of the alliance to develop the content of the workshops, to use their community-based contacts to gain access to young people, and to facilitate the workshops. I agreed to observe how the alliance developed and delivered the workshops, and to survey young people about their experiences. The small scale of the project - one pilot workshop followed by a series of three workshops in three different locations - meant the research would be primarily exploratory. The alliance recognised this, but hoped that the workshops could 'start conversations.' The identities of people in the alliance, the young people, and the locations of the workshops have been kept confidential.

\footnotetext{
${ }^{15}$ The Author XXXX

${ }^{16}$ The Author XXXX
} 
The alliance had hoped that the workshop series would be attractive to schools. But it soon became clear that neither the alliance nor the researcher who was working with them had enough contacts within the education system to make this happen. While the alliance secured access to an integrated school for the first series of workshops, a decision was soon made to approach community-based youth groups.

In the first phase of the project, the alliance agreed the content and format of the workshops. I also interviewed some participants in the alliance about their own experiences and perspectives on militarism. The alliance's main concern was to share how they felt Northern Ireland's cultures of militarism had shaped their own experiences of radicalisation as young people; and to encourage young people to reflect on the horror, rather than the heroism, of war. They hoped that sharing their experiences would help young people gain self-awareness of their own vulnerability to militarism and radicalisation. It is important to point out that the alliance has no official membership. It is a loose network of men who have built up relationships with each other through their community-based work or activism in other organisations. While the alliance is cross-community to the extent that it includes Protestant-Unionist-Loyalist (PUL) and Catholic-Nationalist-Republican (CNR) perspectives, it is notable that all those from CNR backgrounds would be considered 'non-aligned' republicans. Non-aligned republicans do not identify with Sinn Féin and seek an all-Ireland socialist republic. None of the men were involved in what might be called 'mainstream' excombatant groups. Indeed, non-aligned republicans might dismiss some of those groups as simply toeing the Sinn Féin party line. I did not see it as my role as a researcher to comment on the cross-community composition of the alliance or to direct them in how they decided which ex-combatants would speak to young people. The purpose of the research was not to engage with ex-combatants with a range of cross community perspectives; rather, it was to observe how an already-existing network of men came together to address what they 
identified as a problem of militarism in their communities.Analysis of other projects such as 'Prisons to Peace' (further discussion below) convinced the alliance that a series of workshops where young people were prepared for their encounters with ex-combatants would be more beneficial, rather than a one-off guest speaker visit. ${ }^{17}$ The first workshop would establish ground rules for the group and introduce key concepts such as militarism, radicalisation, and alternative approaches to history. This would be conducted by the facilitator, who has a doctoral degree in history and a background in working with young people. The second workshop would feature an interview-style discussion, where the facilitator would interview one or two ex-combatants about their experiences. The third workshop would be a processing session, in which young people could share their reactions to the previous two workshops and raise further questions. This workshop would conclude with an anonymous written survey. The surveys would gather information such as gender, age, denominational affiliation (if any), church attendance (if any), and participation in groups or activities such as the Boys or Girls Brigade, the Army Cadet Forces, flute bands, parading, republican clubs, GAA or 1916 Societies. These multiple choice options would be tailored to the known background demographics of each group, i.e. whether the groups were mixed, PUL or CNR. The groups or activities listed on the multiple choice menu could be considered potential indicators of exposure to cultures of militarism, although it was acknowledged that not all these groups or activities might promote or reinforce militarism to the same degree (or at all, in some circumstances). Young people also would be asked to what extent they thought their community, family or church supported, sympathised with, critiqued or never mentioned paramilitarism, the British Army, or militarism in general. Finally, they would be asked if the workshops had changed any of their ideas, and what they liked and disliked about the workshops. All workshops would be overseen by a teacher or

\footnotetext{
${ }^{17}$ Emerson, 'Conflict, Transition and Education for "Political Generosity".'
} 
youth leader associated with each group, who could provide pastoral support and aftercare if necessary. The researcher interviewed a youth leader from each group several weeks after the workshops to gain further feedback.

During this phase, the alliance delivered a one-off pilot workshop in July 2016 at Summer Madness, a primarily Protestant Christian festival. Summer Madness features lectures, workshops, music and social activities for teenagers and people in their early $20 \mathrm{~s}$. The facilitator chaired a discussion between a former loyalist ex-prisoner and a former member of the British Army. Young people could ask questions after their remarks. Of the 40-50 people who attended, 21 returned the print surveys. One wrote, 'It has given me greater appreciation of how people can be radicalised'; another wrote that they liked 'hearing different views and thinking outside the box.' On the other hand, several indicated that they thought the former British Army speaker was 'too anti-Army' and that this had meant that other perspectives were not acknowledged, such as the use of force as self-defence. This pilot gave the alliance confidence that their perspectives on militarism and radicalisation could open young people up to new ways of thinking; on the other hand, it alerted them that being perceived as 'too anti-Army' could turn some young people off and shut down critical thinking.

After Summer Madness, the alliance pursued contacts in schools, pitching the series of workshops primarily to Religious Education (RE) teachers. They felt that Northern Ireland's cultures of militarism were reinforced and in part created by religion, so the content could be relevant to RE. Because the alliance includes people from British Army, loyalist and republican ex-prisoner backgrounds, workshops could be arranged so that schools could host ex-combatants from so-called single-identity or cross-community perspectives, depending on their preference. Finally, a RE teacher in an integrated school hosted the workshop series 
between December 2016-January 2017. ${ }^{18}$ By this time, the alliance had been pursuing contacts in community-based youth groups, and secured a series of three sessions for March 2017 with a PUL group. Other contacts opened the way with a group of young people from Irish language and non-aligned republican backgrounds. Due to time constraints, the three sessions were condensed into a day-long workshop in June 2017. Though not representative of young people in general, the three sets of workshops allowed the alliance to engage with young people with a range of backgrounds.

\section{Cultures of Militarism in Northern Ireland}

For me, one of the most intriguing aspects of this research was the existence of an alliance of ex-combatants who 'make sense' of their experiences through the conceptual lens of cultures of militarism. This is quite different from many of Northern Ireland's ex-combatants, who have made sense of their experiences by saying that in the past violence was justified - but now it is not. Analysis of interviews with the alliance revealed that for them, cultures of militarism included both ideational and structural aspects. In terms of ideas, the alliance spoke about how growing up they heard discourses that glorified violence and the use of armed force. In terms of structures, they spoke about how institutions like churches and schools reinforced militaristic ideals. They spoke about three main cultures of militarism, aspects of which can be supported by scholarly literature: British Armed Forces, loyalist and republican. ${ }^{19}$

In Northern Ireland, the scholarly emphasis on the 'ethno-national' nature of the conflict has meant that few have focused on militarism and its effects. Feminist critiques of militarism or critical studies of masculinity have been neglected, or dismissed as of little

\footnotetext{
${ }^{18}$ In Northern Ireland, most schools are segregated along denominational lines. Integrated schools deliberately mix pupils from CNR and PUL backgrounds.

19 The Author, XXXXX.
} 
analytical value. ${ }^{20}$ This parallels a lack of awareness of or discourses about militarism in the public sphere. While the concept of 'culture' has been used to analyse Northern Ireland, I know of no other scholars who have used 'cultures of militarism' as an analytical lens. This is surprising, as militarisation is readily apparent in society and politics. A few scholars have recognised this, with Smyth writing of a broad process of militarisation, ${ }^{21}$ Ashe using the term 'militarised masculinities, ${ }^{22}$ Ashe and Harland writing of 'troubling masculinities' ${ }^{23}$ Magee describing loyalism as a 'military masculinity', ${ }^{24}$ and Deiana critiquing the link between ethno-national identities and masculinities, which have cast men as heroic defenders of identity and women as passive supporters. ${ }^{25}$ Beyond that, Wahidin has studied female combatants, challenging the idea that military cultures are always masculine, ${ }^{26}$ and Brewer has demonstrated how policewomen in the Royal Ulster Constabulary coped with a

\footnotetext{
${ }^{20}$ Fidelma Ashe and Ken Harland, 'Troubling Masculinities: Changing Patterns of Violent Masculinities in a Society Emerging from Political Conflict', Studies in Conflict and Terrorism, 37, no 9 (2014): 747-762.

${ }^{21}$ Marie Smyth, 'The Process of Demilitarisation and the Reversibility of the Peace Process in Northern Ireland', Terrorism and Political Violence, 16, no. 3 (2004): 544-566.

${ }^{22}$ Fidelma Ashe, 'Gendering War and Peace: Militarized Masculinities in Northern Ireland', Men and Masculinities, 15, no. 3 (2012): 230-248.

${ }^{23}$ Ashe and Harland, 'Troubling Masculinities.'

${ }^{24}$ David Magee, 'The Deconstruction of Violent Masculinities among Ulster Loyalists', Ph.D. thesis (University of Aberdeen, 2013).

${ }^{25}$ Maria-Adriana Deiana, 'Women’s Citizenship in Northern Ireland after the 1998 Agreement', in Politics and Gender in Ireland: The Quest for Political Agency, eds. Fiona Buckley and Yvonne Galligan (London: Routledge, 2015).

${ }^{26}$ Azrini Wahidin, Ex-Combatants, Gender and Peace in Northern Ireland: Women, Political Protest, and the Prison Experience (Basingstoke: Palgrave Macmillan, 2016).
} 
masculine occupational culture by exaggerating their own femininity or overplaying their masculinity. ${ }^{27}$

Paralleling its neglect in Northern Ireland, militarism had fallen out of favour in peace and conflict studies more generally. Enloe's pathbreaking work on militarisation in international relations helped revive interest. ${ }^{28}$ Writing from a feminist perspective, she defined militarisation as $^{29}$ :

... a step-by-step process by which a person or a thing gradually comes to be controlled by the military or comes to depend for its well-being on militaristic ideas. ... Militarisation, that is, involves cultural as well as institutional, ideological, and economic transformations.

Broad-based definitions of militarism also were developed in historical sociology. Shaw conceived of militarism as 'the penetration of social relations in general by military relations' and the 'relationship of war preparation and society'. ${ }^{30}$ Mann variously defined militarism as 'a set of attitudes which regards war and the preparation for was as a normal and desirable activity'31; and 'the persistent use of organised military violence in pursuit of social

\footnotetext{
${ }^{27}$ John D. Brewer, 'Hercules, Hippolyte and the Amazons - or Policewomen in the RUC,' British Journal of Sociology, 42, (1991): 231-247.

${ }^{28}$ Cynthia Enloe, Maneuvers: The International Politics of Militarizing Women's Lives (Berkeley: University of California Press, 2000); Bananas, Beaches and Bases: Making Feminist Sense of International Politics (London: Pandora Press, 1989). See also the work of feminist scholars Laura Sjoberg and Sandra Via, Gender, War and Militarism: Feminist Perspectives (Westport, CT: Praeger, 2010) and Sandra Whitworth, Men, Militarism and UN Peacekeeping: A Gendered Analysis (Boulder: Lynne Rienner, 2004).

${ }^{29}$ Enloe, Maneuvers, 3.

${ }^{30}$ Martin Shaw, Post Military Society: Militarism, Demilitarisation and War at the End of the Twentieth Century (Cambridge: Polity, 1991): 9-15.

${ }^{31}$ Michael Mann, 'The Roots and Contradictions of Modern Militarism', New Left Review 1, no. 162: 35-50, 35.
} 
goals. ${ }^{32}$ In an observation that resonates with the territory that later became Northern Ireland, Mann argued that historically, Western 'settler' populations often developed a 'horrendous' form of 'civil society militarism', using organised violence for 'social purposes.'33

Enloe also argued that militarisation privileges masculinity and is intertwined with patriarchy, which she defined as 'the system that links militarized feminities to militarized masculinities in a way that sustains the domination of certain brands of masculinity, while keeping women in their assigned places. ${ }^{34}$ Cockburn further characterized 'patriarchal gender relations' as a 'root cause' of war, because they are constitutive of unequal power relationships in cultures and social systems. ${ }^{35}$ Enloe, Cockburn and other feminist scholars make a strong case that conceptions of militarism are incomplete if they do not seriously consider the different roles that men and women play in creating and sustaining it.

In recent years, concepts like militarism and militarisation have begun to come into their own, as evidenced in a number of special issues and edited volumes. ${ }^{36}$ This work is indebted to the insights of feminist theory and historical sociology. Stavriankis and Selby's

\footnotetext{
${ }^{32}$ Michael Mann, 'Authoritarian and Liberal Militarism: a contribution from comparative and historical sociology', in S. Smith, K. Booth, \& M. Zalewski, Eds., International Theory: Positivism and Beyond (Cambridge: Cambridge University Press, 1996): 221-239, 224.

${ }^{33}$ Mann, ‘Authoritarian and Liberal Militarism', 235.

${ }^{34}$ Cynthia Cockburn and Cynthia Enloe, 'Militarism, Patriarchy and Peace Movements,' International Feminist Journal of Politics 14, no. 4 (2012): 550-557, 552-553.

${ }^{35}$ Cynthia Cockburn, 'Gender Relations as Causal in Militarisation and War,' International Feminist Journal of Politics 12, no. 2 (2010): 139-157, 149.
}

36 Anna Stavrianakis and Maria Stern, eds. Special issue on 'Militarism and Security: Dialogue, Possibilities and Limits', Security Dialogue 49, no. 1-2 (2018); Synne L. Dyvik and Lauren Greenwood, eds. Special issue on 'Embodying Militarism - Exploring the Spaces and Bodies In-Between', Critical Military Studies 2, no. 1 (2016); Anna Stavriankis and Jan Selby, eds., Militarism and International Relations: Political Economy, Security Theory (London: Routledge, 2013). 
important collection on Militarism and International Relations explicitly adopted feministinformed sociological approaches, developing an understanding of militarism as 'embedded within society.' 37

The insights from this broader scholarship parallel those of the alliance. The men assured me they were not reading feminist theory and historical sociology; rather their insights were gleaned from their personal experiences of their communities. Taken together, there are three main insights. First, cultures of militarism include ideational aspects, expressed through discourses, images, symbols and rituals. These ideational aspects differ across contexts. But they share a common assumption that violence is justified, and in some cases, violence is desirable or even sacred. Second, cultures of militarism are perpetuated through institutional structures outside 'official' military institutions, such as schools, churches, business, fraternal organisations, sporting associations and scouting associations. The pervasiveness of military values in these institutions embeds militarism in societies and politics. Third, cultures of militarism are predominantly masculine, casting women as subordinate actors. ${ }^{38}$ Cultures of militarism create and perpetuate significant power imbalances between men and women. This third aspect was present, but not as prominent, among the alliance's narratives. The concept of cultures of militarism also resonates with what Jackson calls 'the social construction of war across all levels of society. ${ }^{39}$ He writes ${ }^{40}$ :

\footnotetext{
${ }^{37}$ Anna Stavriankis and Jan Selby, 'Militarism and International Relations in the Twenty-first Century', in Stavriankis and Selby, eds., Militarism and International Relations.

${ }^{38}$ Marjoke Oosterom, 'Gendered (In)security in South Sudan: Masculinities and Hybrid Governance in Imatong State', Peacebuilding 5, no. 2 (2017): 186-202; Annick TR Wibben, 'Why we need to Study (US) Militarism: A Critical Feminist Lens', Security Dialogue, 49, no. 1-2 (2018): 136-148.

39 Jackson, 'Post-Liberal Peacebuilding and the Pacifist State', 4.

${ }^{40}$ Ibid, 4.
} 
Of particular importance in the construction of organised violent conflict is the role played by collective beliefs, public narratives, everyday social and cultural practices, history, conflict discourses and other discursive factors and meta-structures. Within the matrix of factors which make political violence possible in specific localities, is the almost universally accepted doctrine of the legitimacy and efficacy of the instrumental use of violence as a means of attaining political goals.

Jackson's description of 'the social construction of war across all levels of society' could serve as a shorthand definition of cultures of militarism. Northern Ireland's three cultures of militarism are distinct, but internally diverse. British Armed Forces and loyalist cultures of militarism overlap in some aspects. ${ }^{41}$

\section{British Armed Forces culture of militarism}

The British Armed Forces culture of militarism locates the legitimate use of violence in the state security forces and police. There has been surprisingly little analysis of British state militarism within the Protestant-Unionist-Loyalist (PUL) community, especially given that recruits from Northern Ireland make up 20 percent of the British Armed Forces Reserves. When it is considered that Northern Ireland has only about three percent of the UK population - and almost half of Northern Ireland's population is unlikely to identify with the UK state - that means that Northern Ireland Protestants, Unionists, and Loyalists join the

\footnotetext{
${ }^{41}$ There is a potentially vast literature that could be drawn on to support the content of each culture of militarism. For more detailed descriptions of these cultures of militarism, see The Author, XXXX.
} 
British armed forces in large proportions. ${ }^{42}$ The British Armed Forces culture of militarism resonates with Todd's 1987 description of an 'Ulster British' ideology and its accompanying ideas, symbols and rituals. These include identification with sacrifices made during the World Wars, the poppy, the flag, the Queen's speeches, and honours like OBEs and MBEs. ${ }^{43}$ It also overlaps with the loyalist culture of militarism in some aspects.

In interviews, the members of the alliance from the PUL community described how they were influenced by a British Armed Forces culture of militarism, which extended from the British Army all the way through the UDR and the Royal Ulster Constabulary (RUC). This former member of the British Army grew up near a peace line, and felt that his community was under attack from republican paramilitaries. He described how institutions like schools and churches worked together to support a culture of militarism that ultimately resulted in him joining the Army:

From a very early age in unionism there's a heavy influence of militarism. I was in the Boys Brigade. So from a very early age I was drilling ... being taught minor survival tactics ... going out camping or things like that. ... That led to me joining the Army Cadet Force at my school.... So at [age] 13 or 14 I was being trained to shoot a 22 rifle. ... I grew up in the violence of the " 70 s, and I knew only violence. With that sort of influence on my life, and the fact that I was growing up 200 meters from a peace line, where I was witnessing Irish republican violence in my community - I

\footnotetext{
${ }^{42}$ Belfast Telegraph 'Veterans in NI Deserve Same Care', http://www.belfasttelegraph.co.uk/news/northernireland/veterans-in-ni-deserve-same-care-30685369.html, (22 October 2014) accessed 3 June 2016.

43 Jennifer Todd, 'Two Traditions in Unionist Political Culture', in Irish Political Studies Reader: Key Contributions eds. Conor McGrath and Eoin O’Malley (London: Routledge, 2008): 119. Todd's 1987 article in Irish Political Studies is reproduced in this volume, from which the quotation is taken.
} 
wanted to hit back. The Army and the Navy and the Royal Marines had done recruitment processes within our school.... I drifted into the army at 16.

He went on to speak about how he felt that some churches supported militarism:

Any church I was in had their own Boys Brigade or Scouts. So that form of drilling and that indoctrination to a disciplined life was revealing. Certainly in any of those churches I would have went into you would have saw the Regimental Colour, which are the Queen's colours of various old regiments. They were basically bedecking altars, and there was a very, very great pride in what was the proud military tradition of the British Army. In addition to that, there was actually active encouragement at some times. So for example, when I joined the Army, one of my references was written by [a Christian minister], along with [a reference from] my headmaster - to go into the Parachute Regiment at age 16.

The structures and institutions which support the British Armed Forces culture of militarism could include churches, the Orange Order, the media, and schools, where youth army cadet forces are promoted. Even organisations like the Boys' and Girls’ Brigades, which are attached to churches and remain popular, feature military-style uniforms and drill.

\section{Loyalist culture of militarism}

The loyalist culture of militarism emphasises that for centuries loyalists have been 'under siege' and must defend themselves. Loyalists nurture a sense of sacrifice for the British Empire and state, with the loss of the $36^{\text {th }}$ Ulster Division at the Somme conceptualised as a 
blood sacrifice through which their place in the United Kingdom was secured. The popular slogan 'For God and Ulster' echoes a Calvinist theology that designated Ulster Protestants as God's 'elect' or 'chosen people.' Such ideals are conveyed through symbols and the commemoration of events, including the Battle of the Boyne; the $36^{\text {th }}$ Ulster Division going over the top; and paramilitary gunmen in balaclavas. Protestant Christian symbols are popular, especially on Orange banners, and include images such as the open bible, or the bible with a crown. Flags are ubiquitous, including Union Jacks, Northern Ireland flags, and 'historic' Ulster Volunteer Force (UVF) flags, which are claimed by proponents to mark the formation of the historic UVF in 1912, and by critics to valorise the contemporary paramilitary UVF. Rituals include Orange parades, in which Orangemen are accompanied by flute bands, which almost always wear military uniforms and play martial airs. Many loyalists perceive themselves as losing out since the Agreement, and in that context marching seems to have taken on even more importance, with the numbers of parades increasing.

A former loyalist ex-prisoner in the alliance said that the Troubles convinced him that a paramilitary response would be a more effective way to counter republican attacks than joining the British Army or police. Although he did not hear anything in his Sunday School or church that justified violence, he felt he was encouraged by other religious leaders to turn to violence. He spoke about how religious ideas such as the Pope or the Catholic Church being the anti-Christ justified violence towards Catholics, and made him understand life in terms of an apocalyptic battle between good and evil:

You certainly would have heard people who were religious talking about [the Pope or the Catholic Church being] the anti-Christ. You heard people like [Rev Ian] Paisley or 
[Rev] William McCrea couching the war in terms of an apocalypse and we're on the right side. $^{44}$

He believed PUL political leaders radicalised young Protestants in a way similar to how some young Muslims are radicalised today:

I remember one thing that was said was, 'We have to arm ourselves and liquidate the enemy.' I remember thinking that's not ambiguous, this sounds just like what we're doing, so [I will] do that. ... It sounds like war, fighting, killing, shooting and justification for that. So all those things together I think created people who were prepared to kill people and shoot people and feel that it's right. And I think there's parallels in the world today with Islam.

The structures and institutions that perpetuate this culture of militarism include paramilitary organisations, to the extent that they continue to exist within loyalist communities. Political parties that justify the violence of the past also perpetuate cultures of militarism, as both the Democratic Unionist Party and the Ulster Unionist Party could be said to do through their participation in rituals around and articulation of heroic discourses about the World Wars. Cultures of militarism also are perpetuated by institutions like the Orange Order, schools or churches. Magee emphasises the socio-structural conditions that shape loyalist military masculinities: '[Loyalists are] economically and politically relatively powerless, an

\footnotetext{
${ }^{44}$ Paisley and McCrea were prominent ministers in the Free Presbyterian Church. Paisley founded the Democratic Unionist Party.
} 
'underclass'.... This relative powerlessness is a contributing factor in continuing Loyalist violence. $^{45}$

\section{Republican culture of militarism}

The republican culture of militarism glorifies the idea that the Irish nation will be birthed through violent rebellion against British rule. Ashe argues that there are two ideal types of masculinity reproduced in this culture - the 'hard man' gunman willing to take up arms, and the hunger-striker martyr. ${ }^{46}$ These ideas are perpetuated through depictions of key symbols and events, including the Easter Rising/Easter lily/Phoenix symbol, hunger strikers (whose depictions resemble Christ), the H-blocks where they were imprisoned, images of paramilitaries (including men and women in both active military and support roles), remembrance gardens with lists of fallen volunteers, the Irish tricolour, and parades commemorating events such as the Easter Rising or Bloody Sunday. Parades may include men and women dressed in historic or contemporary military gear, concluding with graveside orations where republican ideals are articulated.

The structures and institutions that perpetuate this culture of militarism include paramilitary organisations, to the extent that they continue to exist within republican communities, and the political parties that justify the violence of the past, whether the Easter Rising (Sinn Féin and the Social Democratic and Labour Party) or during the Troubles (Sinn Féin). Gaelic Athletic Association (GAA) clubs, schools or churches also may contribute to a culture of militarism through symbols or discourses- though their justifications for violence

\footnotetext{
${ }^{45}$ Magee, 'The Deconstruction of Violent Masculinities among Ulster Loyalists,' 25.

${ }^{46}$ Ashe, 'Gendering War and Peace'.
} 
and promotion of militarism vary depending on their location. Finally, in deprived urban areas violence is more likely to be seen as justified and attractive. ${ }^{47}$

Led by Sinn Féin, there has been a shift towards the idea that historical republican violence, such as during the Troubles was justified - but now violence is not justified. Socalled 'dissident' republican paramilitaries continue to equate their ongoing violence with the violence of the past, claiming that it is justified. But both historic and contemporary justifications for violence perpetuate a culture of militarism by framing violence as a legitimate, even moral, option.

\section{Ex-combatants' working definition of cultures of militarism}

Based on their personal experiences and observations, the alliance developed a working definition of cultures of militarism, which was introduced to each group of young people:

The belief or desire of a government that a country/tribe/demographic group should maintain strong military capability and be prepared to use it to generate violence to secure or promote national interests. At national level it also implies the glorification of the ideals of a professional military class and the predominance of the armed forces in institutions, the budget and propaganda of the State.

This definition focuses on a state culture of militarism. This reflects the fact that the majority of participants in the alliance are from British Army backgrounds. It also reflects their parallel involvement with the UK-based Veterans for Peace (VFP) organisation, which focuses on the actions of the British Government, describing its purpose as 'increasing public

\footnotetext{
${ }^{47}$ Ashe and Harland, 'Troubling Masculinities'.
} 
awareness of the cost of war and [restraining] our government from intervening in the internal affairs of other nations, for the larger purpose of world peace. ${ }^{48}$ However, the facilitator also told pupils that paramilitarism would be included in the discussion.

During discussions the conception of cultures of militarism was much richer than this written definition. The facilitator and speakers raised questions about how militarism extends to everyday life through social institutions such as churches, flute bands, sporting associations, schools and so on. It is possible that this ad hoc broadening of the definition could have resulted in an unclear definition of militarism for the young people.

\section{Results}

The research confirmed that young people have little awareness of militarism, the dangers of radicalisation, or alternative historical perspectives on the Troubles. Answers to the survey questions also indicated that some young people could be vulnerable to Northern Ireland's cultures of militarism. Participants were asked if they had participated in a range of groups or events that could potentially be associated with cultures of militarism (Table 1). ${ }^{49}$ Respondents could tick all the answers that applied. $\mathrm{N}$ indicates the total number of respondents. The number in parenthesis beside each percentage indicates the total number of respondents for that choice. The inclusion of N/A in the table indicates that choice was not presented to that group.

In the integrated school, most pupils had not participated in any of these activities or events - including all five who indicated they were Catholic and 67\% of those who said they

\footnotetext{
${ }^{48}$ Veterans for Peace UK website, http://vfpuk.org/about/, accessed 27 February 2018.

${ }^{49}$ For the purposes of this limited research project, these are the indicators of cultures of militarism. They were identified by the alliance.
} 
had no denomination (no respondent identified as from a Protestant denomination). In the PUL youth group a slight majority, 56\%, had not participated in any of these activities or events. Participation was greatest from the Irish language/non-aligned republicans, where $70 \%$ were members of 1916 Societies, $80 \%$ had participated in republican parades and/or commemorations, and $100 \%$ had participated in the GAA. The inclusion of the GAA could be considered contentious; however, the broad ideational/structural conception of cultures of militarism described above includes sporting associations.

[Table 1 here]

Participants were also asked their perceptions of their community's support for paramilitaries and/or the armed forces, in the past and in the present (Table 2). Respondents could tick all the answers that applied. Although the small number of respondents skews the results (seemingly large differences in percentages can be a difference of just one or two people), it is striking that in the integrated school and in the PUL youth group, more young people thought that support and sympathy for both paramilitary activity and state military forces was higher today - a supposed time of peace - than in the past. The highest figure comes from the PUL group, where $79 \%$ thought their community supported or sympathised with paramilitary activity today. By way of contrast, in the Irish language/non-aligned republican group, only $36 \%$ thought their community supports or sympathises with the cause that motivates the Irish republican armed struggle today, as compared to $73 \%$ who thought their community supported that cause in the past. At the suggestion of the alliance, the survey questions for this group used the language of 'armed struggle' rather than paramilitary activity. It was thought that this language would resonate better with the group. We did not ask about support for state military forces because it could be fairly safely assumed that CNR communities 
would not support the British military, and the Irish military is not a factor in this context. Given that the Irish language/non-aligned republicans were more likely than the others to participate in groups or activities that could be associated with cultures of militarism, it is striking that they thought their community would be less supportive of armed force today. Finally, across the three groups, there is little evidence that people within their communities criticise violence or militarism. This could indicate that the use of force or the values of militarism are taken for granted or fairly firmly embedded within communities.

[Table 2 here]

The research also confirmed that the workshops opened participants up to new perspectives on militarism and on history. In the integrated school, participants interacted with the facilitator and a former member of the British Army, who was a past pupil. When asked whether listening to the speakers had given them new ideas or changed any of their ideas, ten of the 14 pupils said yes. They were asked to write in examples, which included: 'It's made me think different about the military and see it's not as good as it's made out to be. It has also let me think about things from the other side of the community'; 'After listening to him speak about the Army, for me wanting to be a nurse in the Army, it has sort of put me off it'; and 'The story from the past pupil has to a certain extent changed my view of the army. ... I have considered joining the Royal Air Force as a backup career and I would like to hear somebody's personal experience of the Air Force.' Pupils also were asked an open-ended question about what they liked or disliked about the workshops. Three mentioned they liked learning about militarism, which was a new concept for them. One pupil wrote: 'I liked learning about a different topic like militarism and getting an understanding of what it is.' Most pupils said they appreciated hearing about people's personal experiences of the 
Troubles and/or the Army. However, some said that there was 'too much talking', indicating they would have preferred a more dialogic engagement rather than a limited time for questions and answers. Others questioned whether the perspectives presented had been 'onesided.' One wrote: 'While the speaker and the interview person talked I thought that they only talked about the negatives about the army. When might there be positives?'

In the PUL group, participants interacted with the facilitator and a former loyalist exprisoner. Ten participants filled in the question about whether the workshops had given them new ideas or changed any of their ideas. Six said no and four said yes, with write-in answers for 'yes' including: 'Not to be prejudiced'; 'It makes me further emphasise the fact that we should be proud of our country as well as its culture and heritage'; 'Yes and no, it made me think more about what if the Troubles started again'; and 'Gave me more of an understanding.' When asked what they liked or disliked about the workshops, all 13 wrote that they had learned a lot, especially about their own history. One wrote, 'I liked how it gave me wider knowledge of what happened in the past. I learnt things I never knew'; while another wrote, 'I liked learning about the Troubles because I wouldn't be knowledgeable in that area and listening to real life stories was very interesting. I also like how we weren't pressured to agree with their decisions.' In an interview a few weeks after the final workshop, the youth worker said that he had been speaking with the young people informally about the workshops. He was most struck by how the workshops revealed 'how little the young people know about the history of the Troubles.' He also said that the young people wanted more time for discussion and questions.

The workshops with the Irish language/non-aligned republicans were delivered in a one-day session on a Saturday. They were not a unified group that met together regularly. Rather, the young people were involved in Irish language groups and 1916 Societies in a 
number of towns. 1916 Societies describe themselves as 'an Irish separatist movement'; 50 they are usually identified with non-aligned republicans. Many of these young people had part-time jobs or were at university, and their youth leaders thought it would be too challenging to organise a three-week series of events that everyone would be able to attend. This group heard the stories of the former UDR/British Army facilitator and a former republican ex-prisoner who now identifies as non-aligned. The workshops were originally to be held in a youth club premises. But it was deemed too contentious for the surrounding community to bring a former UDR man to this venue, so the workshops were moved to a hotel in another town.

In an interview, a youth worker explained that he and other youth workers posted on Facebook and sent out emails describing the event as an opportunity to hear a former republican ex-prisoner and a former UDR man talk about their experiences of the Troubles. He said many in the group would be 'politically active' in the sense of having been involved in the 1916 Societies' 'One Ireland, One Vote' campaign for a referendum on Irish unity. The 1916 Societies describe this campaign as 'a means to resolve the constitutional conflict in Ireland [that] seeks to end partition, establish a Government of National Unity and rebuild the Sovereign All-Ireland Republic., ${ }^{51}$

On the day, there were not many questions from the floor. The youth worker attributed that to a lack of preparation work with the group prior to the workshop. A survey question tailored to this group asked, 'Do you think the Stormont Assembly and devolved rule will deliver a lasting peace? Why or why not?' All 11 participants said 'no.' The write-in explanations included: 'I feel the Stormont fiasco will only divide the two communities further'; 'Brexit has resulted in six counties wanting Britain out of the EU which could result

\footnotetext{
${ }^{50} 1916$ Societies webpage, http://1916societies.com/about-us/, accessed 28 February 2018.

${ }^{51} 1916$ Societies webpage, http://1916societies.com/about-us/, accessed 28 February 2018.
} 
in disturbing the peace again'; and 'It is green and orange. I think it should be young people in Stormont, not people fixed on the past.' The youth worker said the workshops helped him realise just how little the young people were engaging with people from other backgrounds. He recalled that during the workshop he had asked them, 'How much do you discuss postconflict issues or reconciliation on an everyday basis?' He noted that, 'It was quite a muted response. But any that did respond just said, "No, this is not something that's talked about." ... It would appear that the people we're dealing with are not availing of those opportunities in any meaningful way or looking for those opportunities even.'

\section{Concluding Discussion}

This research was small-scale and focused on particular demographic groups, which limits its generalisability. But it confirmed the hypotheses the alliance developed based on their experiences in their communities: young people have little awareness of militarism, the dangers of radicalisation, or alternative historical perspectives on the Troubles. These findings take on added urgency in light of the uncertainty around the effects of Brexit on the border, and a possible poll for Irish unity. Conditions could be ripe for Northern Ireland's 'insurgent margins' to return to more overt violence.

But few peacebuilders in Northern Ireland and other contexts have offered a sustained challenge to militarism. The alliance is one nascent and small-scale example of what Jackson calls 'post-liberal peace plus': local peacebuilders critiquing militarism in both its state and paramilitary forms.$^{52}$ Despite its promise as an example of 'post-liberal peace plus,' the alliance's achievements are limited. It has not been able to offer a sustained challenge to cultures of militarism that has reached a large number of young people, or found its way into

\footnotetext{
52 Jackson, 'Post-Liberal Peacebuilding and the Pacifist State,' 9-15.
} 
public debates. Having said that, the research confirmed that most young people valued the experience of engaging with ex-combatants and hearing them challenge cultures of militarism, even if they did not agree with them. Some young people indicated their perspectives had changed and that they were more critical of militarism, but the engagement between the ex-combatants and young people was too limited to expect significant and widespread changes in perspective. This was a limitation that was recognised from the start, and was reflected in the alliance's more modest goal to 'start a conversation.' Given the lack of awareness or discussion of militarism in Northern Ireland in general, it is significant that young people expressed an interest in the topic and, in some cases, indicated that they wanted further opportunities to talk about it.

Jackson also argues that 'post-liberal peace plus' should revive pacifist and nonviolent approaches to peacebuilding. Such approaches could include deliberately incorporating marginalised groups in democratic processes, replacing state militaries with unarmed civilian defence forces, and empowering unarmed peacekeeping missions. The alliance did not push conversations with young people very far in these directions. But both ex-combatants and young people are groups that often are marginalised in post-conflict societies. So the alliance's attempt at 'starting a conversation' could be considered a step towards empowerment of these groups. ${ }^{53}$ Women are similarly marginalised in post-conflict settings. Jackson does not mention including feminist perspectives in the non-violent repertoire of 'post-liberal peace plus.' But feminist scholars have been among the most prominent critics of militarism and military masculinities, ${ }^{54}$ and Richmond and Mac Ginty

\footnotetext{
${ }^{53}$ Simic and Milojevic, 'Dialogues between Ex-Combatants and Youth in Serbia'; Helen Berents and Siobhan McEvoy-Levy, eds. 'Special Issue on Theorising Youth and Everyday Peacebuilding', Peacebuilding, 3, no. 2 (2015).

${ }^{54}$ Anna Stavrianakis and Maria Stern, 'Militarism and Security: Dialogue, Possibilities and Limits', Security Dialogue 49, no. 1-2 (2018): 3-18; Cynthia Cockburn, 'Gender Relations as Causal in Militarisation and War',
} 
have argued that 'gender analysis' is vital to peacebuilding research and practice. ${ }^{55}$ The gender dynamics of militarism were not entirely absent from the workshops, arising during questions with the integrated school and PUL group. But gender dynamics could be included more systematically in conversations. The alliance also could incorporate gender analysis in a new, fuller working definition of cultures of militarism. Another limitation of this project was that young people reported they did not have much time for discussion, which may have further confirmed their subordinate political position. On this, it should be noted that my department's ethics committee cautioned against allowing too much discussion among young people, for fear of causing distress. Given the young people's appetite for an interactive approach, it would be worthwhile for future engagements to facilitate more in-depth discussion.

While Jackson advocates remaining uncompromising on pacifist approaches, in practice this seemed to shut down debate with young people: some participants reported that 'anti-Army' perspectives dominated and that alternative perspectives on the Army should be considered. The alliance has no defined position on whether anti-militarism equates with pacifism or non-violence, but is open to exploring the possibilities of these and other approaches. Accordingly, it could be worthwhile to include 'just war' perspectives in workshops. Following Jackson, alternatives such as unarmed civil defence forces also could be introduced. In response to a question in the integrated school, the facilitator mentioned civil defence forces as an alternative to militaries, but this was a one-off reference. In Britain, the VFP organisation with which some of the alliance are involved has worked alongside

International Feminist Journal of Politics 12, no. 2 (2010): 791-803; Synne L. Dyvik and Lauren Greenwood, 'Embodying Militarism - Exploring the Spaces and Bodies In-Between', Critical Military Studies 2, no. 1 (2016): 1-6.

${ }^{55}$ Richmond and Mac Ginty, 'Where now for the Critique of the Liberal Peace?', 184. 
Quakers to produce resources that articulate pacifist positions and practical alternatives to violence. ${ }^{56}$ Such resources also could be drawn on in future conversations. The limited pilot funding meant that more ambitious, long-term work with young people was out of the question. Future engagement would benefit from a longer series of workshops that would expand on these themes, equipping young people for more constructive conversations with ex-combatants and with each other.

While the alliance can be considered an anti-militarist group, it does not compare easily to other cases of anti-militarist activism elsewhere, which often focus on anti-arms trade, anti-base, and anti-conscription struggles. Two key insights from research on antimilitarism could usefully inform the alliance's work. First, Cockburn has discovered that many women anti-militarism activists are forming women-only groups, in large part because male activists fail to take them seriously. ${ }^{57}$ She urges women and men to work together, opposing war 'in their own gender identity' in order to root out militarised masculinities and femininities. ${ }^{58}$ The alliance could benefit from actively seeking out women's participation and contributions in their work. Second, Rossdale has alerted us to the ways in which antimilitarist groups often mirror the hierarchical structures and decision-making of military institutions. Rossdale urges a commitment to 'prefiguration' within such groups, which involves a conscious modelling of non-hierarchical leadership and consensus-based decision making, ${ }^{59}$ a form of 'counter-conduct' that also has been an aspiration of the Occupy

\footnotetext{
${ }^{56}$ Quaker Peace and Social Witness, ‘The New Tide of Militarisation’ (2014).

${ }^{57}$ Cynthia Cockburn, Antimilitarism: Politics and Gender Dynamics of Peace Movements (London: Palgrave, 2012).

${ }^{58}$ Cockburn, 'Gender Relations as Causal in Militarisation and War', 154.

${ }^{59}$ Chris Rossdale, 'Enclosing Critique: The Limits of Ontological Security,' International Political Sociology 9 (2015): 369-386, 382-383.
} 
movement. ${ }^{60}$ To that end, the alliance could benefit from embarking on a self-critical process through which it examines not just the results of the surveys with young people - but also asks how the group itself might change its internal practices in light of this research. Engagement between ex-combatants and young people around cultures of militarism has the theoretical potential to be a transformative example of 'post liberal peace plus.' But in Northern Ireland, the alliance faces considerable challenges. Most peacebuilding funding is distributed by state actors like the British and Irish Governments or European Union. It is far from clear that state actors would support a project that challenges militarism, especially in state forms. This is likely to be the case in other contexts as well. Indeed, Jackson identifies the key challenges of 'post-liberal peace plus' as overcoming 'the deep cultural acceptance of military violence by political elites, the general public, states, and international organisations,' among other factors. ${ }^{61}$ The alliance might be more likely to secure funding from private donors or states with small militaries or civilian defence forces, but these usually have more limited resources. It seems that the very critique of state militarism that makes the alliance such a compelling example of 'post-liberal peace plus' demonstrates not only the theoretical potential - but also the practical obstacles - of building a radical post-liberal peace.

\footnotetext{
${ }^{60}$ Chris Rossdale and Maurice Stierl, 'Everything is Dangerous: Conduct and Counter-Conduct in the Occupy Movement,' Global Society 30, no. 2 (2016): 157-178.

${ }^{61}$ Jackson, 'Post-Liberal Peacebuilding and the Pacifist State,' 15.
} 